\title{
Varafolkloorsetelt vokaalzhanridelt lauluni III
}

\author{
Ingrid Rü̈tel
}

\section{Laulu mõiste ja laulu kujunemine läänemeresoomlastel}

Tänu spetsiifilisele funktsioonile ja otstarbele eksisteerisid kõik eespool kirjeldatud zhanrid regilauluga kõrvuti, tihti viimasega assimileerudes, omandades selle poeetilisi elemente ja kohandudes värsimõõdult. Osa neist elas koguni üle regilaulu eluea, jätkates eksisteerimist uuema, riimilise rahvalaulu kõrval kas iseseisvalt ja eraldi (karjasehuiked ja kutsungid, jahimeeste peibutusimitatsioonid jm) või ka uuema rahvalaulu vormi- ja stiilivõtteid omandades (näit mõned hälli- ja lastelaulud - Rüütel 1980).

Enamikku ülalmainitud zhanridest on märgitud ka neilt läänemeresoome rahvastelt, kellel puudub runolaul (resp. regivärsiline, kalevalamõõduline, allitereeruv jne) rahvalaul. Nad kuuluvad arhailiste kultuuride universaalsete fenomenide hulka ja olid olemas ka läänemeresoomlastel tõenäoliselt juba enne kalevalamõõdulist laulu, kuigi täienesid hiljem uute alaliikide, tüüpide ja tekstimotiividega. Mõningail juhtudel võivad niisugused nähtused (näiteks improviseeritud hällilaulud, töörütmi koordineerivad või kaubapakkumisel esitatavad hõiked jne) tekkida isegi tänapäeval seoses aktuaalsena püsinud otstarbe ja funktsiooniga.

Osa loitse, hälli-, laste- ja ahellaule on täiesti regivärsivormilised, kuigi võivad omada erijooni esituses, muusikas jne. Hoolimata teatavaist assimilatsiooni- ja segunemistendentsidest (peamiselt regilauluga, aga mõnevõrra ka uuema rahvalauluga) säilitasid kõik need zhanrid autonoomsuse ja spetsiifika mitte üksnes funktsioonilt, vaid ka väljendusvahenditelt.

Matti Kuusi paigutab ahellaulud varasemate kalevalalaulude hulka (Kuusi 1963). Soome ja karjala traditsioonis nad ongi tihti kalevalamõõdulised. Ent arvestades asjaolu, et see iidne rahvusvaheline zhanr on tuntud ka neile läänemeresoome rahvastele, kel puudub kalevalamõõduline laul (vepslased, liivlased), ning kaugematele soomeugrilastele, aga samuti baltlastele, slaavlastele, germaanlastele jt (Laurinkiene 1981), teisalt ilmutavad ka läänemeresoomlaste runolaulule mitteomaseid jooni, võib arvata, et ahellauluvorm kuulub siiski runolaulueelsete nähtuste hulka või on paralleelselt arenenud iseseisev fenomen. Osa ahellaule võib olla ka runolaulu kõrvale laenulistel eeskujudel tekkinud. Ahellaulude aluseks on Eestis nagu teistelgi rahvastel enamasti 3-4 rõhualaga rõhuline värss, mis on omane ka eesti lastemängituslauludele, samuti tuleb ette loitsudes ja muinasjutulauludes.

Itkud, karjasehelletused, linnulaulud jm imitatsioonid arenesid samuti mõnedest karakteersetest runolaulutunnustest (eelkõige alliteratsioon) hoolimata omaette ja eri teid pidi.

Tekib küsimus, kas meil ongi üldse tegemist lauludega või pigem laulueelsete fenomenidega (vrd Zemtsovski 1983). 


\section{Mis on laul?}

Mõiste määratlemisel on kasulik pöörduda rahva enese ettekujutuste ja rahva-terminoloogia poole. Vana läänemeresoome sõna laulu, laulemahan oli esialgu kasutusel eeskätt just runolaulu kohta, hiljem aga üle kantud ka muudele, uuematele nähtustele (uuem rahvalaul, kirikulaul, kooli- ja koorilaul jne). See sõna esineb kõigil läänemeresoome rahvastel, kel on olemas runolaul (resp. regilaul), samuti liivlastel.

Spetsiaalsed vana rahvalaulu tähistused on eri rahvastel, aga ka sama maa eri piirkondades erinevad, sealjuures tavaliselt võõra algupäraga ning ilmselt tekkinud hiljem, et eristada vanu rahvalaule mistahes uuematest lauludest. Kõige üldisemalt ongi esimesi nimetatud Eestis lihtsalt vanadeks lauludeks või siis nende funktsioonist lähtuvalt kiigelauludeks, lõikuslauludeks jne. (Kihnus nimetatakse enamikku regilaule pulmalauludeks, kuna need säilisid kauem just pulmades ja olid lauldavad samal üldviisil).

Ühist läänemeresoomelist rahvapärast terminit vanema rahvalaulu jaoks eraldi ei ole olemas. Ka teaduslikus kirjanduses kohtab erinevaid nimetusi (runolaul, kalevalamõõduline ehk kalevalalaul soomlastel, regivärsiline laul ehk regilaul eestlastel, tõlkeis sageli allitereeruv laul jne). Sõna laul kehastab läänemeresoome keeltes, nagu ka paljudel teistel rahvastel, poeetilise teksti ja meloodia lahutamatust, kusjuures algselt puudus omaette sõna ka meloodia tähistamiseks.

Meloodiat tähistatakse üksikuis läänemeresoome keeltes erinevate sõnadega, mis on reeglina laenatud teistelt rahvastelt (eestikeelne sõna viis näiteks arvatakse pärinevat alamsaksa keelest, kuid sama sõna on tuntud ka rootslastel laulu tähenduses).

Sõna viis on meil ilmselt küllalt vana, see tähistas algselt ka vanade laulude meloodiaid, esinedes muu hulgas laulutekstides endis (näiteks lüürilistes lauludes, kus öeldakse, et laulik sai sõnad tööd tehes, viisid aga viie linnu suust jne). Paljude esitajate hilisemaid teateid, et vanadel lauludel polnudki viisi, oli vaid hääl, toon, mõnu, moll vms, võib ilmselt käsitada kui vanade laulude viiside vastandamist uuemate rahvalaulude, kirikulaulude jm hilisemate laulude meloodiatele, mis neist oluliselt erinesid.

Regilaule on alati lauldud, st esitatud viisiga. Itke, loitse, hõikeid, karjasehelletusi, pulmahõiskeid jne ei nimetata tavaliselt lauludeks ega nende esitust laulmiseks. See kehtib ka laste- ja ahellaulude kohta, kui neid esitati ilma fikseerunud meloodiata, analoogselt loitsudega - kas tavalises kõnes, vabarütmilise retsitatiivina või siis skandeeriti kindlas taktimõõdus, kuid ilma kindlakujulise meloodiata.

Niisugune esitus ongi mainitud zhanrides ilmselt algsem, kuna hiljem on seotud nendega mitmesuguseid vanemaid või uuemaid rahvaviise või siis lihtsalt improviseeritud mingit meloodiat, sageli vabalt varieerides selle meloodiajoonist ja ka vormi, mis pole iseloomulik runolauludele. Viimastes kasutati reeglina küll lihtsaid, tihti kõneintonatsioonile lähedasi, kuid ikkagi kindla traditsiooni päraselt muusikaliselt formeerunud meloodiaid. Palvele laulda mõnd lastemängitamise või ahellaulu võib rahvaluulekoguja tihtipeale saada vastuseks, et see polegi laul, vaid muidu ütlemine, lugemine või sõnad, et neid ei lauldud, vaid loeti, üteldi, jorutati jne. Siiski tunnistatakse, et nende esitus erineb tavalisest kõnest.

Soomlastel on selliste lastelaulude jaoks kasutusel sõna loru (Lipponen 1984). Vepslased, kel puudub kalevalamõõduline laul, nimetavad oma laule pajodeks, mis lähtub sõnast pajattaa ja tähendab vepsa keeles laulmist (vrd valgevene bajati), teistel läänemeresoomlastel aga tavaliselt rääkimist või jutustamist.

Itke, huikeid, karjasehelletusi, loitse ei nimetata samuti tavaliselt lauludeks. Nende tähistamiseks kasutati erilisi, sageli deskriptiivseid ning reeglina algupäraseid väljendeid. Samu sõnatüvesid kasutati ka nende zhanride esitamise kohta. Nii nimetatakse eesti keeles loitse tihti lihtsalt sõnadeks (tulesõnad, saunasõnad jne), kusjuures mõiste ise kätkeb endas ka maagilise tähenduse (sõnas ära). 
Küll nimetatakse aga lauludeks laululisi vaheosi muinasjuttudes, hoolimata nende retsitatiivsest, kõnelähedasest esitusest ja ebaregulaarsest rütmist, ilmselt vastandades neid muinasjuttude proosatekstile, millest nad oma vormilt selgesti eristuvad, kusjuures selline eraldamine on kunstikavatsuslik (Salve \& Sarv 1987). Samuti kasutatakse sõna laulma hällilaulude, ka lihtsate äiutuste puhul. Lauludeks nimetatakse ka lindude häälitsusi ning nende imitatsioone (mainitagu võrdluseks, et mõnedes Aafrika keeltes linnud, vastupidi, kõnelevad).

Kindlat piiri ühelt poolt laulu ja arhailiste vokaalzhanride vahel ning teisalt laulu ja lihtsalt improvisatsioonilise vokaalse eneseväljenduse vahel ei ole. Nii tekstilt kui ka muusikalt on vaadeldavais vokaalzhanrides erinevaid laululisuse arengujärke.

Mis puutub sõnalis-poeetilisse teksti, siis osal kõnealustel zhanridel pole üldse sõnu, neid esitatakse kas mingil häälikul või asemantilistel silpidel (huiked, helletused, äiutused). Teised sisaldavad küll sõnu, kuid kindla poeetilise struktuurita. Nad seisavad nagu kõne ja luule piirimail ja on seejuures suuresti improvisatsioonilised. Neiski on poeetilise teksti formeerumise aste erinev. Lõpuks kuulub siia traditsiooniliste poeetiliste väljendusvahenditega ja invariantse struktuuriga tekste, nagu loitsud, ahellaulud ja lastelaulud, laulud muinasjuttudes, teataval määral ka itkud, kuigi neis on vormilisi vabadusi enam ja improvisatsiooni osa suurem kui lauludes.

Erinev võib olla ka teksti ja viisi vahekord. Ka poeetiliselt väljakujunenud ja invariantse struktuuriga tekstidel ei ole enamasti meloodiat selle sõna tavalises tähenduses - neid esitatakse tavalisel kõneintonatsioonil, loetakse monotoonselt, ühetaoliselt või retsiteeritakse pool-lauldes, pool-kõneldes, hõigatakse, halatakse läbi nutu jne. Seejuures võib esitus olla vabarütmiline, kõnerütmi järgiv või kindlas taktis. Viimasel juhul võib fraasi rõhuliste positsioonide arv olla kindel või muutuv, rõhutute silpide arv aga reeglina ebapüsiv, varieeruv.

Kõnealustes zhanrides on reeglina tegemist kas rõhulise värsimõõdu või siis heterosüllaabilise vabavärsiga (viimaselgi on oma reeglid ja piirangud). Kuigi neis võib kohata kaheksasilbikut, erinevad nad mõlemad printsipiaalselt runolaulu kvantiteerivast (pikkade ja lühikeste silpide regulaarsel vaheldusel põhinevast) värsimõõdust.

Ebaregulaarne värsimõõt seostub tavaliselt kõneintonatsiooniga - laskuva üldsuunaga meloodialiikumisega, mille väikesed tõusud ja langused on kooskõlas sõnade või sõnaühenditega: helisageduse tõusud vastavad rõhulistele, langused rõhututele silpidele, kusjuures kõige enam on helikõrguslikult esile tõstetud sõna esimene, pearõhuline silp. Helikõrguslik kulminatsioon ühtib reeglina lauserõhuga.

Regulaarse taktimõõdu puhul (hälli- ja mängituslaulud, töörütmi koordineerivad hõiked, mõned loitsud, ahellaulud jm) võib meloodia baseeruda ühelainsal toonil, mida iga silbiga korratakse, või kahel helil - kulmineeruva ja langusheli vaheldumisel, mis saadavad vastavalt rõhulisi ja rõhutuid silpe. Intervallidena kohtame sagedamini väikest tertsi, kuid esineb ka suurt sekundit, samuti suuremaid intervalle. Võib ette tulla ka kõikuvat või laskuvat tonaalsust, ebamääraseid ja muutuvaid intervallisuhteid, kõnelähedast retsiteerivat intoneerimist kindlas taktis.

Loitsude, lastelaulude, helletuste jm mitterunovormiliste arhailiste vokaalzhanride esituses segunevad tihtipeale erinevad intoneerimisviisid - retsitatsioon, laul, rütmiline skandeerimine, hõikeintonatsioonid, harilik kõne. Näiteks võib kindlas taktimõõdus skandeerimine või vabarütmiline, retsiteeriv esitus lõppeda hõikega või üle minna tavaliseks kõneks jne.

Kuigi ka regiviise iseloomustatakse sageli kui kõnelähedasi, on retsitatiivsuse ja laululisuse aste neis ning vaadeldavais varafolkloorsetes liikides kvalitatiivselt erinev nagu improvisatsiooni määrgi. Nn kõnelähedased regiviisid ei kujuta endast siiski mitte kõne ja laulu piirile jäävaid retsitatiive, vaid kõneintonatsiooni muusikalist üldistust, millel on konkreetne heliastmestik ja meloodiline struktuur. See ei välista 
muidugi rahvaviisile omast variaablust, seejuures on võimalikud ka üksikute helirea astmete ja intervallide kõikumised.

Vaadeldavais varafolkloorsetes vokaalzhanrides võib muusikalise väljenduse arenguaste, helilaadiline ja meloodiline fikseeritus suuresti erineda. Võib kohata erinevaid muusika arengustaadiume. Osa hälli- ja lastelaule, loitsulisi töölaule jm on täiesti regivärsivormis ja neid esitati tavaliselt regiviisidel. Teine osa, olles samuti muutunud lauluks selle sõna tavalises tähenduses, on säilitanud silmapaistva zhanrilise eripära nende meloodiline ja vormiline areng on kulgenud runoviisidest erinevalt, neile on omased spetsiifilised meloodiakäigud ja viisitüübid jne. Nii näiteks eristuvad Mustjala kihelkonna muude runoviiside taustal tüpoloogiliselt markantselt hällilaulude viisid (Rüütel 1980), Mulgimaal tõusevad omapärase liigina esile karjasehelletused (Vissel 1990) jne.

Siiski näib, et läänemeresoomlaste rahvapärases arusaamises laulust ei ole muusikalist külge eriti eelistatud. Nii näiteks on karjasehuigetest välja kasvanud helletused, mis sisaldavad ka karjasepillilugude intonatsioone, meloodiliselt üks kõige arenenumaid vokaalzhanre läänemeresoome laulutraditsioonis (Rüütel 1988). Sellele vaatamata ei nimetata neid lauludeks ja nende esitust laulmiseks, vaid asemantilistest silpidest tulenevate deskriptiivsete terminitega - helletused, aetused, oetamised jne (vrd soome huhuilut). Tavalisest laulust eristab neid ebaregulaarne vorm, samuti asemantiliste häälikukombinatsioonide rohkus.

Seega eeldab läänemeresoomlaste laulu mõiste nii meloodia kui ka poeetilise teksti olemasolu.

Kindlasti ei saa laulu mõistet üldisemalt siduda mingi konkreetse, üksnes teatavaile kultuuridele omaste vormitunnustega, näiteks lõppriimi või stroofivormiga, nagu pakuvad mõned leksikonid. Stroofid puuduvad runolaulus, need pole omased ka varasemale Euroopa rahvalaulule. Nii näiteks on keskaegsele saksa rahvalaulule iseloomulik nn Zeilenmelodie, kus iga rida sisaldab meloodiakaare, mis varieeruvad ja asetuvad laulu kestel vabalt ümber, grupeerumata püsivaiks struktuurideks (Müller-Blattau 1932). Rootsist on veel XVII saj fikseeritud vaba, ebaregulaarse vormiga ballaade ja hällilaulude viise (Johnson 1980) jne.

Laulu vormi- ja stiilitunnused võivad eri kultuurides erineda, nagu võib oluliselt erineda ka laulu mõiste ja sellele omistatavad tunnused. Nii kuulub mõnedel Siberi rahvastel laulu mõistesse eelkõige tavalisest kõnest erinev tämber ja intoneerimisviis, kuna tekst, samuti meloodia tavalises tähenduses puuduvad hoopis, näiteks nn kõrilaul (vene k gortannoje penije) tshuktshidel, eskimotel jt).

\section{Laul ja improvisatsioon. Isikulaulud ja joiud}

Mõiste rahvalaul folkloorizhanri tähenduses, folkloristliku terminina, eeldab nagu mistahes muu folkloorinähtuski kindlasti mingi püsiva, variantides (korduvatel esitustel) säilitatava invariantse struktuuri, teatava traditsioonilisuse alge olemasolu, vastandudes seega improvisatsioonidele. Viimased võivad samuti sisaldada traditsioonilisi väljendusvahendeid, kuid ei muutu traditsiooniliseks lauluks, vaid tekivad ja kaovad, süttivad hetkeks ja kustuvad sealsamas. Nad võivad lülituda traditsiooni vaid sel juhul, kui neid esitatakse korduvalt, kui nad vastavad traditsioonilistele vormi- ja stiilimallidele ning sotsiaalsele nõudlusele.

Improvisatsiooni kujunemisel mingi traditsioonilise folklooriliigi osaks, antud kontekstis lauluks, kohtame erinevaid traditsioonilisuse astmeid.

Selles suhtes väärivad tähelepanu nn isikulaulud, mis eksisteerivad paljudel PõhjaEuroopa ja Siberi rahvastel, Põhja-Ameerika indiaanlastel ja eskimotel, soomeugrilas- 
test aga laplastel, hantidel ja mansidel, maridel. Siia võiks ehk arvata ka komi autobiograafilised improvisatsioonid (isikulaulu ja «saatuselaulu» vahel ei ole kindlat piiri, kuna ka esimesed on sageli aja jooksul kaotanud oma esialgse maagilise tähenduse).

Teaduslikus kirjanduses nimetatakse isikulaule sageli improvisatsioonideks. Mõnedel rahvastel (näiteks lamepea-indiaanlastel - vt Merriam 1967) tähendab isikulaul üksnes erilisel viisil omandatud, maagilise tähendusega meloodiat, sõnad puudusid hoopis. Teistel (näiteks obiugrilastel) sisaldab see teatavat meloodiat ja vabalt improviseeritavat teksti, millel algselt puudub püsiv vorm. Paljusid isikulaule esitatakse korduvalt, sageli koguni teiste isikute poolt, kuna nad kanduvad edasi autori (omaniku) sugulastele ja tuttavatele - tavaliselt küll mitte kaugemale kolmest sugupõlvest (Schmidt 1981). Seejuures omandavad nad kollektiivse loomingu jooni. Kuigi nad alluvad varieerumisele, säilitavad nad siiski teatava stabiilsuse. Éva Schmidt nimetab neid «stabiilseteks isikulauludeks» (Schmidt 1981: 153). Seejuures kannavad nad reeglina informatsiooni autorist, neid esitatakse tavaliselt kellegi lauludena, keda tuntakse või tunti.

Sellistele isikulauludele on mõneti sarnased eesti uuemasse rahvalaulu kuuluvad külalaulud (nn kohalik külakroonika), mis jutustavad konkreetsetest isikutest ja tõestisündinud juhtumustest külas (Rüütel 1974). Teatavasti on ka isikulaulud, näiteks koolalaplastel ja obiugrilastel vahel süzheelised, vestavad kellestki ja millestki (Schmidt 1981; Lappalainen 1984). Sellised on tegelikult ka mordva lüürilised laulud, milles kõneldakse tavaliselt humoristlikus toonis kellestki konkreetsest isikust (vt SurajevKoroljov 1969).

Nii eesti külakroonika kui ka soomeugrilaste isikulaulude puhul on tegemist suhteliselt lähimineviku repertuaariga (esimesed on üldse uuem nähtus, teised aga, nagu öeldud, ei säili reeglina üle paari-kolme sugupõlve), mistõttu on võimalik vahel sammsammult jälgida individuaalloomingu levikut suulises traditsioonis, varieerumist ja transformeerumist rahvalauluks (Rüütel 1974; analoogsetest protsessidest rahvajuttudes vt Proodel-Hiiemäe 1974).

Isikulaulud pakuvad suurt teaduslikku huvi ka kui sõnadeta laulud. Sõnad võivad neis hoopis puududa, tekst võib koosneda

a) mingist vokaalist, asemantilisest silbist või siis

b) ühest-kahest sõnast või sõnapaarist, mis korduvad ja vahelduvad asemantiliste silpidega. Esimest rühma esindavad näiteks mõnede Põhja-Ameerika indiaanlaste maagilise kaitsefunktsiooniga isikulaulud (Merriam 1967), teist eskimote isikulaulud (Pelinski 1981). Kuid on olemas ka pikema poeetilise tekstiga isikulaule, kus asemantilised silbid puuduvad üldse või on hoopis vähemolulised. Väärib tähelepanu seegi, kuidas eri rahvad neid nimetavad, kas ühise mõistega «laul» või kuidagi teisiti.

Läänemeresoomlastele nii keelelt kui territoriaalselt lähim isikulaule omav rahvas on saamid (laplased), kelle etnogenees on tänaseni teaduses lõplikult lahendamata (vt Kantola 1984: 6-7, Uibopuu 1984: 80-85 jt). Geneetikute uusimad uurimused, mille tulemused esitati Jyväskyläs viimase fennougristide kongressi lõpp-plenaarettekandes, viitavad nende sootuks erilisele päritolule. Varasemail aegadel on joigudel olnud nähtavasti usundiline funktsioon (Lappalainen 1984: 16).

Läänelaplaste laulud koosnevad üksnes asemantilistest silpidest või siis rohkete asemantiliste silpide vahele lükitud üksikuist sõnadest või lühifraasidest (Kantola 1984: 38). Põhjalaplaste lauludes on sõnalise teksti osa suurem, kuid asemantiliste silpide rohkus on neilegi iseloomulik.

Lääne- ja põhjalaplastel on ka ühine muusikastiil ja eriline intoneerimismaneer, mida nimetatakse onomatopoeetilise sõnaga juoigat. Siit tuleneb ka sõna juoigus, mis on kasutusel peamiselt läänelaplastel, kuna põhjalaplastel on samas tähenduses enam levinud sõna luötti või luohti. 
Lääne- ja põhjalaplaste isikulauludel on mõndagi ühist lõunaeesti karjasehelletuste, -aetuste, -õetustega (needki nimetused tulenevad vastavaist refräänsõnadest või -silpidest), ja seda nii vormi kui funktsiooni poolest. Nimelt olid ka need eri karjastel erinevad, identifitseerudes konkreetsete isikutega. Helletuse järgi võis ära tunda helletaja.

Seega oli neil peale spetsiifilise kasutuse, mis seostus karjaseametiga, veel teinegi funktsioon, mis lähendab neid isikulauludele - nad funktsioneerisid teatava isiku tähistajana. Lapi joiud omakorda on seotud karjaseametiga, olles põdrakarjuste laulud. Helletustele lähendavad neid ka sarnased asemantilised silbid (vrd Itkonen 1963: 14).

Koolalaplastel pole sõnadeta laule. Nende isikulauludele on iseloomulik jutustav tekst, kus asemantilised silbid kas puuduvad hoopis või funktsioneerivad refräänidena. Ka viisid on lääne- ja põhjalaplaste joigudest täiesti erinevad (Travina 1987; J. Sarv 1982). Koolalaplased ei tunne ka onomatopoeetilist nimetust juoigus, oma laule nimetavad nad levde, leudd või levud, (Itkonen 1963; Lappalainen 1984; Laitinen 1981; Sarv 1982). Nimetatud sõnad nagu ka põhjalaplaste luötti ning inarisaamidel tuntud livde tulenevad vanaskandinaavia sõnast ljód mis tähendas laulu.

Teatavasti on ka koolalapi keel tunduvalt erinev muudest lapi murretest. Näib, et ka nende laulud ei ole geneetiliselt seotud joigudega, kuigi mõningad kokkupuutepunktid on ilmsed. Pigem lähenevad nad obiugrilaste isiku- või saatuselauludele, samuti komide «autobiograafilistele improvisatsioonidele» (vt Mikushev 1976).

Lõpuni lahendamata on Karjala joigude probleem. Joigudeks nimetatakse erilisi laule Loode-Karjalas, mis on vormilt lähedased itkudele, kuid mille sisuks on tavaliselt noormehe lüüriline jutustus oma armuasjadest. Lapi joigudega seovad neid eelkõige nimetus ja asemantilised refräänid, samuti vabam, suuresti improvisatsiooniline tekst. Nende kohta kasutatakse onomatopoeetilisi väljendeid joijunta või hehetys, mis tulenevad eelkõige refräänsõnadest (Stepanova \& Koski 1977: 307).

\section{Kokkuvõtteid ja järeldusi}

Kõigest eelnevast võib teha mõned üldisemad järeldused.

1. Joige ja joigumist ega muid ainult või peamiselt asemantilistel silpidel või häälikutel esitatavaid vokaliise ei saa pidada läänemeresoomlaste runolaulu peamiseks ajalooliseks eelkäijaks, nagu vahel on arvatud, ega universaalseks laulu eellaseks üldse. Need seostuvad ikkagi vaid teatavate kultuuride või kultuuridialektide ja konkreetsete liikidega ning võivad eri kultuurides kujuneda muusikaliselt vägagi arenenud omaette zhanrideks, nagu seda on näiteks irokeeside tantsulaulud või hilisem kihistus Alpi joodeldusi, aga ka osa saami joige ning Lõuna-Eesti karjasehelletusi.

2. Kõik eespool käsitletud varafolkloorsed vokaalzhanrid osalesid nii või teisiti laulu kui fenomeni kujunemisel. Ka eesti rahvalauludes võib niisiis leida tõestusi erinevatele muusika tekke teooriatele (vt Kunst 1974: 46-49), nagu näiteks

imitatsiooni teooria, mille kohaselt muusika tekkis linnulaulu imiteerimisest;

hüüete, hõigete teooria ning rütmiteooria, mille järgi muusika on tekkinud töörütmi koordineerimiseks vajalikest ja muudest praktilise otstarbega hõigetest;

stressiteooria, mis väidab, et muusika on tekkinud stressisituatsioonis (itkumeloodiad!); 
teooria, mille kohaselt muusika on kujunenud hällitustest ja

lastehüpitustest;

kõnemeloodia teooria;

toonikeelte teooria.

Ühtki neist ei saa absolutiseerida ning muusika ja laulu teket ei saa järelikult redutseerida üheleainsale algpõhjusele.

Uusim teooria muusika tekkest väidab, et keel ja muusika kujunesid ühisest protovõimest, mis oli oma loomult eelkõige muusikaline (Levmann 1992). Hiina ja Tai toonikeelte uurimisel on selgunud, et erinevatel helikõrgustel baseeruvate intonatsioonimallide kasutamine tundmuste väljendamiseks omandatakse ammu enne fonoloogilist väljendusoskust (kõnet). Selline võime on olemas ka loomadel, samuti väikelastel. Selle teooria kohaselt tekkis muusika kui keele-eelne spontaanne enesesäilitamist toetav kommunikatsioonivahend, mille sisu oli mitteleksikaalne, holistiline ning mis väljendus ajas muutuvates helikõrgustes ja spektraalseis sagedustes. Levmanni uurimus näitab, et intonatsioon etendab palju suuremat semantilist ja strukturaalset rolli kui seni arvatud. Varafolkloorsete vokaalzhanride analüüs toetab seda järeldust.

3. Eesti jt läänemeresoomlaste rahvapärases terminoloogias tehakse vahet laulu ja muude traditsiooniliste vokaalzhanride vahel, kusjuures läänemeresoomlased (ja laplased) ei nimeta asemantilistel häälikukombinatsioonidel põhinevaid vokaliise (joige, helletusi jne) tavaliselt lauluks, samuti ei nimetanud nad lauluks ka muid arhailisi zhanre, nagu itkud, loitsud, lastehüpitused, ahellaulud jm, mille esitus erines tavalistest lauludest.

Seega pidasid läänemeresoomlased lauluks üldiselt niisugust vokaalzhanri, mis koosneb teatava struktuuriga poeetilisest tekstist ja meloodiast.

4. Mõistesse rahvalaul folkloristliku terminina, s.o vastava folklooriliigi tähenduses, kuulub tingimata invariantne struktuur, mis säilib korduval esitamisel (variantides) ja mille alusel moodustub teatav konkreetne laulutüüp. See kehtib nii teksti kui viisi kohta, mis on autonoomsed ning ei moodusta igakord püsivaid seoseid (eriti vanemais folkloorikihtides), kuigi nende vastastikused seosed ja suhted pole juhuslikud, vaid alluvad teatavaile, antud kultuurile omastele seaduspärasustele (lähemalt: Rüütel 1989).

5. Improvisatsiooni traditsiooni lülitamise eelduseks on eelkõige traditsiooniline vorm, baseerumine tavapärastel poeetilistel ja muusikalistel väljendusvahenditel. Uued teemad võetakse kergemini omaks kui võõras vorm (lähemalt: Rüütel 1990: 365-366).

Üldse võib traditsioonilisusest folkloristikas kõnelda mitmel eri tasandil, näiteks fenomenoloogilisel, stilistilisel, funktsionaalsel. Võib eristada juhuslikke individuaalseid improvisatsioone ja teatavaile kultuuridele iseloomulikke, võiks öelda, traditsioonilisi improvisatsioone. Viimaste hulka kuuluvad eespool käsitletud isikulaulud ja autobiograafilised improvisatsioonid, aga ka Eestis varem tuntud regivärsilised improvisatsioonid (näiteks pulmalauludes), muuhulgas tänaseni elav improviseerimistava setudel. Asi pole mitte üksnes traditsiooniliste 
stiili- ja vormivõtete kasutamises, vaid traditsioonis (tavas) improviseerida teatud situatsioonis, teatud vormis ja teatud viisil. Just sedalaadi improvisatsioonid võisid minna suulisse käibesse ja kinnistuda traditsioonis, omandada stabiilse, invariantse põhikuju ja muutuda traditsiooniliseks lauluks.

6. Eesti regivärsilise rahvalaulu viiside kujunemisel sai domineerivaks intonatsioonimalliks jutustavale fraasile omane kõnemeloodia, kusjuures kõneläheduse avalduseks ei ole mitte niivõrd kitsas helidiapasoon, vaid pigem muud tunnused - üldine meloodiajoonis ja segmentatsiooni iseloom, meloodia helikõrgusliku kontuuri sõltuvus laulureale vastava kõnefraasi intonatsioonist, kõnelise rütmika elemendid (sõnarõhkude säilimine 3-silbiliste sõnadega värssides, silbipikkuste markeerimine laulmisel), temporaalsed nüansid (näiteks meetrilised pikendused ja peatused fraaside ja pikemate lõikude lõpus), silpe siduvad libistused ja muud esitusiseärasused, mis ilmnevad ka mõnes regilaulueelses vokaalzhanris. Regiviiside algseks funktsiooniks oli edastada ja toetada laulu tekstis sisalduvat sõnumit, mistõttu need kujunesidki eeskätt kõneintonatsiooni muusikalise üldistusena (lähemalt: Rüütel 1986). Sama võib konstateerida ka teiste läänemeresoomlaste vanimate runoviisikihistuste kohta. Rahvalaulu hilisemas arengus kasvas järjest muusika kui iseseisva kunstilise komponendi osatähtsus.

\section{Kirjandus}

Asplund, Anneli 1994. Balladeja ja arkkiveisuja. Suomalaisia kertomalauluja. Suomalaisen Kirjallisuuden Seura. Helsinki.

Bojarkin, N. I. 1981. Pamjatniki mordovskogo narodnogo muzõkalnogo iskusstva. Pod redaktsijei E. V. Gippiusa, sost. N. I. Bojarkin. Tom 1. Mokshanskije priurotshennõje pesni i platshi Mezhduretshja Mokshi i Insara. Saransk.

Bojarkin, N. I. 1986. Mordovskaja instrumentalnaja signalnaja muzõka. Muzõka v obrjadahh i trudovoi dejatelnosti finno-ugrov. Toimetanud I. Rüütel. Tallinn.

Bojarkin, N. I. 1988. Pamjatniki mordovskogo narodnogo muzõkalnogo iskusstva. Pod redaktsijei E. V. Gippiusa, sost. N. I. Bojarkin. Tom 1. Erzjanskije priurotshennõje pesni i platshi Zavolzhja. Saransk.

Itkonen, Erkki 1963. Lappalainen kansanrunous. Suomen kirjallisuus I. Kirjoittamaton kirjallisuus. Toim. Matti Kuusi. Keuruu.

Johnson, Anna 1980. «Sangen i skogen - skogen i skangen» om fäbodarnas musik.

Folkmusikboken. Stockholm.

Kantola Tuula 1984. Talvadaksen joikuperinne. Turku.

Kiuru, Eino \& Koski, Terttu 1974. Narodnõje pesni Ingermanlandii. Leningrad.

Konkka, Unelma \& Gomon, Alla 1977. Karelskije pritshitanija. Soome-ugri rahvaste muusikapärandist. Koost. I. Rüütel. Tallinn.

Korhonen, Mikko 1987. Kalevalamitan varhaishistoriaa. JSFOu 81. Helsinki.

Krasnopolskaja, T. V. 1986. O kompozitsionnõhh ossobennostjahh melostrofõ karelskihh pritshitanii. Muzõka v obrjadahh i trudovoi dejatelnosti finno-ugrov. Toimetanud I.

Rüütel. Tallinn.

Kunst, Jaap 1974. Ethnomusicology. A Study of its Nature, its Problems, Methods and Representative Personalities to Which is Added a Bibliography. Photomechanical Reprint.

Kuusi, Matti 1963. Suomen kirjallisuus I. Kirjoittamaton kirjallisuus. Keuruu. 
Kõiva, Mare 1990. Estonskije zagovorõ. Klassifikatsija i zhanrovõje ossobennosti. Avtoreferat dissertatsii na soiskanije utshenoi stepeni kandidata fil. nauk. Tallinn. Kõiva, Ottilie \& Rüütel, Ingrid 1997. Vana Kannel VII:1. Kihnu regilaulud. Tartu. Laitinen, Heikki 1981. Saamelaisten musiikki. Kansanmusiikki. Helsinki. Lappalainen, Päivi 1984. Dál mí juoiggasta' vel. Anders Ivar Guttormin joikujen tarkasteluja. Turku.

Laugaste (Treu), Eduard 1931. Die estnischen Vogelstimmendeutungen. Helsinki. Laurinkiene, N. I. 1981. Semantika i poetika litovskihh kalendarnõhh pesen. Vilnius. Levmann, Bryan G. 1992. The Genesis of Music and Language. Ethnomusicology XXXVI, Number 2.

Lipponen, Ulla 1984. Kuukernuppi. Vanhoja ja uusia lastenloruja. Helsinki. Merriam, Alan P. 1967. Ethnomusicology of the Flathead Indians. Viking Fund Publications in Anthropology. Number Fourty Four. New-York.

Mikushev, A. K. 1976. Komi improvizatsii i ihh saamsko-ugorskije paralleli. Etnografija i folklor komi. Trudõ IJLI No. 17 Sõktõvkar.

Müller-Blattau, M. 1932. Das deutche Volkslied. Berlin Schöneberg.

Ojamaa, Triinu 1995. Muusika ääremail: nganassaani linnu- ja loomahäälendid. Magistritöö. Tartu. (Käsikiri)

Pelinski, Ramon 1981. La musique des Inuit du Caribou. Montreál.

Pino, Veera \& Sarv, Vaike 1981. Setu surnuitkud I. Tallinn.

Pino, Veera \& Sarv, Vaike 1982. Setu surnuitkud II. Tallinn.

Proodel-Hiiemäe, Mall 1974. Rahvajuttude kujunemisest Kodavere kihelkonnas. Paar sammukest eesti kirjanduse uurimise teed. Uurimusi ja materjale VII. Tartu.

Rüütel, Ingrid 1974. Ida-Saaremaa külalauludest ja laulumeistritest. Keel ja Kirjandus, nr 4-5.

Rüütel, Ingrid 1979. Soome-ugri rahvaste laule: Vadja ja isuri rahvalaule. LP «Melodija». Tallinn-Riia.

Rüütel, Ingrid 1980. Mustjala regiviiside tüpoloogia. Ars Musicae Popularis 1. Tallinn. Rüütel, Ingrid 1986. Tipologija, struktura i razvitije estonskihh odnostrotshnõhh svadebnõhh napevov. Muzõka v obrjadahh i trudovoi dejatelnosti finno-ugrov. Toimetanud I. Rüütel. Tallinn.

Rüütel, Ingrid 1988. Setu rahvalaulude kihistused ja etnokultuuriline taust. Tallinn. Rüütel, Ingrid 1988a. O vzaimosvjazjahh vokalnoi i instrumentalnoi muzõki v estonskom folklore. Narodnõje muzõkalnõje instrumentõ i instrumentalnaja muzõka. II. Moskva. Rüütel, I. 1989. Razvitije pribaltiisko-finskoi narodnoi pesni (problemõ istorii i tipologii). Narodnaja muzõka: istorija i tipologija. Pamjati professora E. V. Gippiusa (1903-1980). Sbornik nautshnõhh trudov. Leningrad.

Rüütel, Ingrid 1990. Tradition and Innovation in Estonian Folk Music Today (on the Material of the Kihnu Traditional Culture). VII. European Seminar in Ethnomusicology. Pre-publication of the conference papers to be presented at the VII. Seminar. Berlin, October 1.- 6., 1990. Berlin.

Rüütel, Ingrid 1994. Istoritsheskije plastõ estonskoi narodnoi pesni v kontekste etnitsheskihh otnoshenii. Ars Musicae Popularis 12. Tallinn.

Rüütel, Ingrid 1997. Estonian Folk Music Layers in the Context of Ethnic Relations. Folklore. Electronic Journal of Folklore. Vol. 6. Edited by Mare Kõiva \& Andres Kuperjanov. Tartu. Sama, elektrooniline versioon: http://haldjas.folklore.ee/folklore Rüütel, Ingrid \& Remmel, Mart 1980. Opõt notatsii i issledovanija vepsskihh pritshitanii. Finno-ugorskii muzõkalnõi folklor i vzaimosvjazi s sosednimi kulturami. Toimetanud I. Rüütel. Tallinn.

Rüütel, Ingrid \& Salve, Kristi 1989. Soome-ugri rahvaste laule: liivi. LP, Melodija. Tallinn-Riia. 
Salmenhaara, A. 1976. Itkuvirsien musiikillisesta hahmotuksesta. Paimensoittimista kisällilauluun. Tutkielmiä kansanmusiikista 1. Kaustinen.

Salve, Kristi \& Sarv, Vaike 1987. Setu lauludega muinasjutud. Tallinn.

Sarv, J. 1982. Arhaitsheskije tshertõ v pesnjahh saamov Kolskogo poluostrova.

Muzõkalnõi folklor finno-ugorskihh narodov: arhaika $i$ sovremennost. Tezisõ dokladov.

Tallinn.

Sarv, Vaike 1986. Vidõ setuskihh pritshitanii i ihh muzõkalnõje ossobennosti. Muzõka $v$ obrjadahh i trudovoi dejatelnosti finno-ugrov. Toimetanud I. Rüütel. Tallinn.

Sarv, V. 1996. Setukaisten itkujen luokittelu. Congressus Octavus Internationalis

Fenno-Ugristarum. Jyväskylä 10.-15.8.1995. Pars VI. Ethnologia \& Folkloristica.

Jyväskylä, 397-401.

Schmidt, Éva 1981. Trends in the 20th Century Ob-Ugric Oral Tradition. Studia Fennica 26. Helsinki.

Stepanova, A. 1985. Metaforitsheskii mir karelskihh pritshitanii. Leningrad.

Stepanova, A. S. \& Koski, T. A. 1977. Karelskije jeigi. Soome-ugri rahvaste

muusikapärandist. Koost. I. Rüütel. Tallinn.

Stockmann, Doris (Hg.) 1992: Volks- und Popularmusik in Europa. Laaber-Verlag.

Surajev-Koroljov G. I. 1969. Mordovskije narodnõje pesni. Saransk.

Zemtsovskii, I. I. 1983. Pesnja kak istoritsheskii fenomen. Narodnaja pesnja. Problemõ

izutshenija. Leningrad.

Tampere, Herbert 1956a. Eesti rahvalaule viisidega I. Tallinn.

Tampere, Herbert 1958. Eesti rahvalaule viisidega III. Tallinn.

Tampere, Herbert 1960. Eesti rahvalaule viisidega II. Tallinn.

Tampere, Herbert 1965. Eesti regivärsilise rahvalaulu meloodika stiilitüübid.

Etnograafiamuuseumi Aastaraamat XX. Tartu.

Tampere, Herbert 1970. «Lindude äratamine» liivlaste traditsioonis.

Läänemeresoomlaste rahvakultuurist. Tallinn.

Tampere, Herbert \& Tampere, Erna 1985. Vana Kannel V. Mustjala regilaulud. Tallinn.

Tedre, Ülo 1972. Eesti rahvalaulud. Antoloogia, III köide, 3. vihik. Tallinn.

Tõnurist, Igor 1976. Muzõkalnõje instumentõ i instrumentalnaja muzõka v narodnom bõtu estontsev. Muzõkalnõi folklor finno-ugorskihh narodov $i$ ihh etnomuzõkalnõje svjazi s drugimi narodami. Tezisõ dokladov. Tallinn.

Travina, I. K. 1987. Saamskije narodnõje pesni. Moskva.

Uibopuu,Valev 1984. Meie ja meie hõimud. Lund.

Vilkuna, Kusta 1946. Työ ja ilonpito. Helsinki.

Vissel, Anu 1986. Estonskije pastusheskije pesni (vidõ, regionalnõje i muzõkalnõje ossobennosti). Muzõka v obrjadahh i trudovoi dejatelnosti finno-ugrov. Toimetanud I.

Rüütel. Tallinn.

Vissel, Anu 1988. Eesti karjaselaulud II. Võrumaa ja Tartumaa karjaselaulud. Tallinn.

Vissel, Anu 1990. Eesti karjaselaulud 3. Mulgimaa karjaselaulud. Ars Musicae Popularis nr 9. Tallinn. 